\title{
Fabrication of Porous Hydroxyapatite through Combination of Sacrificial Template and Direct Foaming Techniques
}

\author{
Sujin Woottichaiwat ${ }^{1}$, Somchai Puajindanetr ${ }^{1, *}$, and Serena M. Best ${ }^{2}$ \\ 1 Department of Industrial Engineering, Faculty of Engineering, Chulalongkorn University \\ Bangkok 10330, Thailand \\ 2 Department of Materials Science and Metallurgy, University of Cambridge, \\ Cambridge CB2 3QZ, UK \\ E-mail: fiespj@eng.chula.ac.th ${ }^{1, *}$
}

\begin{abstract}
The porous hydroxyapatite (HA) bioceramics were prepared through combination of sacrificial template and direct foaming techniques using PMMA granules (varied from 5 to $50 \mathrm{wt} \%$ in content) as a template and $\mathrm{H}_{2} \mathrm{O}_{2}$ solution (varied from 5 to $30 \mathrm{wt} \%$ in concentration) as a foaming agent, respectively. The effects of PMMA content and $\mathrm{H}_{2} \mathrm{O}_{2}$ concentration on final porosity, microstructure and mechanical strengths were studied. The porous samples using PMMA provided the porosity ranging from $52 \%$ to $75 \%$, the samples using $\mathrm{H}_{2} \mathrm{O}_{2}$ had the porosity ranging from $82 \%$ to $85 \%$, and the sample using both pore formers provided the porosity ranging between $84 \%$ and $90 \%$. The higher content of PMMA and concentration of $\mathrm{H}_{2} \mathrm{O}_{2}$ led the porosity increased, leading to a decrease in the compressive and flexural strengths. Furthermore, this combination technique allowed interconnected pores having two levels of pore size, which came from PMMA and $\mathrm{H}_{2} \mathrm{O}_{2}$. The PMMA formed the small pores with the diameter ranging between 100 and $300 \mu \mathrm{m}$, while $\mathrm{H}_{2} \mathrm{O}_{2}$ provided the larger pores with the diameter ranging from 100 to $1,000 \mu \mathrm{m}$ depending on concentration.
\end{abstract}

Keywords: Porous hydroxyapatite, fabrication, sacrificial template, direct foaming.

ENGINEERING JOURNAL Volume 15 Issue 2

Received 16 August 2010

Accepted 24 December 2010

Published 1 April 2011

Online at http://www.ej.eng.chula.ac.th/eng/

DOI:10.4186/ej.2011.15.2.1 


\section{Introduction}

Nowadays, porous bioceramics have an increasingly important role in biomedical application, such as bone filler, orbital implant and drug delivery carriers [1]. One of the most popular topic focuses on porous hydroxyapatite (HA). Since it has a chemical composition $\left(\mathrm{Ca}_{10}\left(\mathrm{PO}_{4}\right)_{6}(\mathrm{OH})_{2}\right)$ identical to human bone and an excellent biocompatibility. Moreover, porous structure provides outstanding bone ingrowths, vascularization and an increased interfacial area between the implant and the tissues resulting in the stronger attachment $[1,2,3]$.

A number of pore forming techniques on bioceramics have been proposed, which can be classified into 3 main techniques [4]. There are (1) replica technique, e.g. replamineform and PU impregnation [5, 6]; (2) sacrificial template technique, e.g. starch consolidation, dual-phase mixing and camphene-based freeze casting [7, 8, 9]; and (3) direct foaming technique, e.g. foaming method and gelcasting [10, 11]. However, almost previous studies were based on using a single technique. A few works focused on porous fabrication using combination of these techniques. Padilla et al. studied on porous HA using combination of PU impregnation (replica) and gelcasting (direct foaming) techniques; and Batulli et al. studied on porous zirconia using polyethylene sphere as a sacrificial template and gelcasting techniques $[12,13]$. In spite of these, it seems no study on fabrication of porous HA using combination of sacrificial template and direct foaming techniques.

The purpose of this study was to characterize the porous HA samples fabricated through combination of sacrificial template and direct foaming techniques using PMMA granules and $\mathrm{H}_{2} \mathrm{O}_{2}$ solution as a pore template and a foaming agent, respectively. Additionally, the effects of PMMA content and $\mathrm{H}_{2} \mathrm{O}_{2}$ concentration on the final porosity, microstructure, compressive strength and flexural strength of the samples were also investigated.

\section{Materials and methods}

\subsection{Preparation of hydroxyapatite powder}

A stoichiometric HA was prepared using the precipitation reaction between 0.5 moles calcium hydroxide (Riedel-de-Haen, Germany) and 0.3 moles orthophosphoric acid (Merck, Germany). The precipitation reaction was performed at room temperature and the $\mathrm{pH}$ was controlled at 10.5 by the addition of ammonium hydroxide solution (APS Finechem, Australia) [14]. During mixing process, the acid solution was slowly dropped into the vigorously stirring suspension, using a peristaltic pump [15]. After complete mixing of the reactants, the suspension was aged overnight. The precipitate was filtered, dried at $80^{\circ} \mathrm{C}$ overnight and then ground to a powder by a pestle and mortar. Subsequently, the powder was sieved with the size of $100 \mu \mathrm{m}$.

\subsection{Fabrication of porous hydroxyapatite}

The poly-methyl-methacrylate granules (PMMA) being commercial grade was applied as a pore former for sacrificial template technique, while hydrogen peroxide solution, $\left(\mathrm{H}_{2} \mathrm{O}_{2}\right)$ was used as a foaming agent for direct foaming technique.

The porous hydroxyapatite ceramics were prepared through three techniques, including sacrificial template, direct foaming and combination between sacrificial template and direct foaming. To fabricate the porous samples, the HA powder was homogeneously mixed with PMMA granule at various content $(5,10,20,30,40$ and $50 \mathrm{wt} \%)$ and $\mathrm{H}_{2} \mathrm{O}_{2}$ solution at different concentration $(5,10,20$ and $30 \mathrm{wt} \%)$, with the liquid to powder ratio (L/P ratio) of $1.3 \mathrm{ml} / \mathrm{g}$. A series of sample name were listed in Table 1 . To evaluate the effect of PMMA content and $\mathrm{H}_{2} \mathrm{O}_{2}$ concentration, the mixtures were prepared without addition of binder, deflocculant and other additives.

After mixing, the paste was placed into removable molds, and kept at $60^{\circ} \mathrm{C}$ overnight. At this temperature, the decomposition of $\mathrm{H}_{2} \mathrm{O}_{2}$ produced the foaming of the paste. Afterwards, the green samples were removed from the molds and then heated at $400^{\circ} \mathrm{C}$ for 1 hour with the slowly ramp rate of $1{ }^{\circ} \mathrm{C} / \mathrm{min}$ for burning out PMMA granules and to avoid the cracking. Finally, the samples were sintered at $1100^{\circ} \mathrm{C}$ for 2 hours with the ramp rate of $5^{\circ} \mathrm{C} / \mathrm{min}$ and then furnace cooled. 
Table 1. The experimental plan layout and feasible production range of porous HA samples (Hxx-Pyy was referred to the sample produced with xx concentration (wt $\%$ ) of $\mathrm{H}_{2} \mathrm{O}_{2}$ solution and yy content (wt $\%$ ) of PMMA granule, and " $X$ " was referred to the handleless sample).

\begin{tabular}{cccccccc}
\hline $\begin{array}{c}\mathrm{H}_{2} \mathrm{O}_{2} \\
\text { concentration } \\
(\mathrm{wt} \%)\end{array}$ & 0 & 5 & 10 & 20 & 30 & 40 & 50 \\
\cline { 2 - 7 } & $\mathrm{H} 00-\mathrm{P} 00$ & $\mathrm{H} 00-\mathrm{P} 05$ & $\mathrm{H} 00-\mathrm{P} 10$ & $\mathrm{H} 00-\mathrm{P} 20$ & $\mathrm{H} 00-\mathrm{P} 30$ & $\mathrm{H} 00-\mathrm{P} 40$ & $\mathrm{X}$ \\
0 & $\mathrm{H} 05-\mathrm{P} 00$ & $\mathrm{H} 05-\mathrm{P} 05$ & $\mathrm{H} 05-\mathrm{P} 10$ & $\mathrm{H} 05-\mathrm{P} 20$ & $\mathrm{H} 05-\mathrm{P} 30$ & $\mathrm{X}$ & $\mathrm{X}$ \\
5 & $\mathrm{H} 10-\mathrm{P} 00$ & $\mathrm{H} 10-\mathrm{P} 05$ & $\mathrm{H} 10-\mathrm{P} 00$ & $\mathrm{H} 10-\mathrm{P} 20$ & $\mathrm{X}$ & $\mathrm{X}$ & $\mathrm{X}$ \\
10 & $\mathrm{H} 20-\mathrm{P} 00$ & $\mathrm{H} 20-\mathrm{P} 05$ & $\mathrm{H} 20-\mathrm{P} 10$ & $\mathrm{X}$ & $\mathrm{X}$ & $\mathrm{X}$ & $\mathrm{X}$ \\
20 & $\mathrm{H} 30-\mathrm{P} 00$ & $\mathrm{H} 30-\mathrm{P} 05$ & $\mathrm{H} 30-\mathrm{P} 10$ & $\mathrm{X}$ & $\mathrm{X}$ & $\mathrm{X}$ & $\mathrm{X}$ \\
30 & & \multicolumn{7}{c}{}
\end{tabular}

\subsection{Characterizations}

The Morphology of the synthesized HA powder and the as-received PMMA granule was characterized using laser particle size distribution analysis (LPD) and scanning electron microscope (SEM). In addition to the morphological study, SEM was also applied to observe the microstructure of the porous HA samples.

The phase purity of the sintered HA powder was analyzed using X-ray diffraction (XRD) with $\mathrm{CuK}_{\alpha}$ radiation. The scanning range of $2 \theta$ was between $20^{\circ}$ and $50^{\circ}$ at the scan speed of $0.5^{\circ} \mathrm{min}$.

The decomposition temperature of the PMMA granules was determined by thermo-gravimetric analysis (TGA) using simultaneous thermal analyzer (STA) with the heating rate of $10^{\circ} \mathrm{C} / \mathrm{min}$.

The porosities of the sintered samples were calculated from the bulk density of the sample $\left(\rho_{\text {bulk }}\right)$ and the theoretical density of hydroxyapatite $\left(\rho_{H A}=3.156 \mathrm{~g} / \mathrm{cm}^{3}\right)$, by Eq (1).

$$
\text { Porosity }=\left(1-\frac{\rho_{\text {bulk }}}{\rho_{H A}}\right) \times 100 \%
$$

To examine the effect of PMMA content and $\mathrm{H}_{2} \mathrm{O}_{2}$ concentration on the porosity, the one-way analysis of variance (ANOVA) was performed at the significant level $(\alpha)$ of 0.05 . In addition, such results were used to develop regression models to predict porosity.

The compressive strength and three-point flexural strength of porous HA samples were characterized according to ASTM C773-88 and C1161-02c specification, respectively.

\section{Results and discussion}

\subsection{Characteristics of the HA powder and PMMA granule}

Figure 1 showed particle size distribution of the HA powder and the PMMA granule. The distribution of the HA powder was a bimodal distribution with the peaks of approximately $4 \mu \mathrm{m}$ and $20 \mu \mathrm{m}$ in particle size, while that of the PMMA granules was an unimodal distribution with a peak of approximately $150 \mu \mathrm{m}$. The average and standard deviation of mean particle sizes of the both were summarized in Table 2. The average mean particle sizes of the HA powder and PMMA granules were $4.97 \pm 0.03 \mu \mathrm{m}$ and $150.75 \pm 0.15 \mu \mathrm{m}$, respectively.

Figure 2 exhibited SEM micrographs of the HA powder and PMMA granules. In Fig. 2(a), the HA powder had angular particles with various sizes. This may be due to the manually milling process through a pestle and mortar. This is similar to the results from previous investigation by Gibson et al [14]. The larger particles appeared to be the agglomeration of smaller particles during sintering process. In Fig. 2(b), the PMMA granules obviously had a spherical shape with various sizes, ranged from 10 to $200 \mu \mathrm{m}$. 


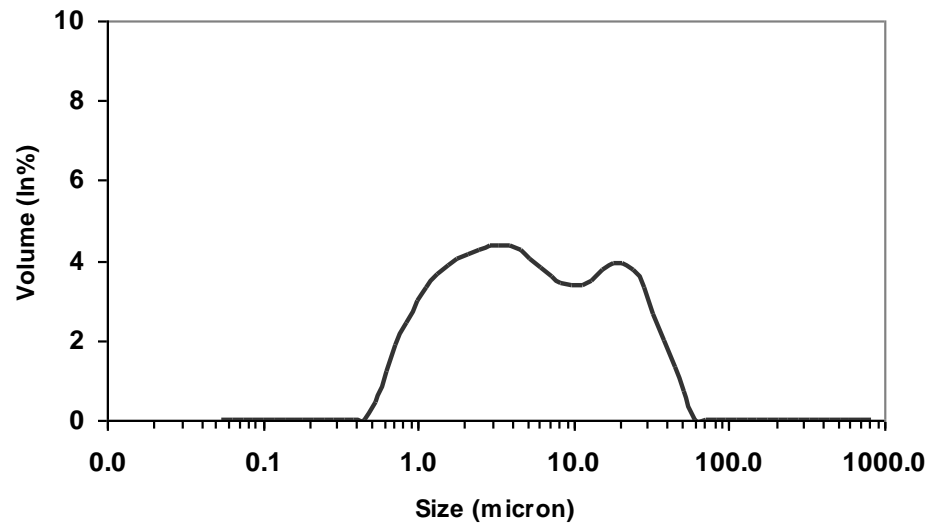

(a)

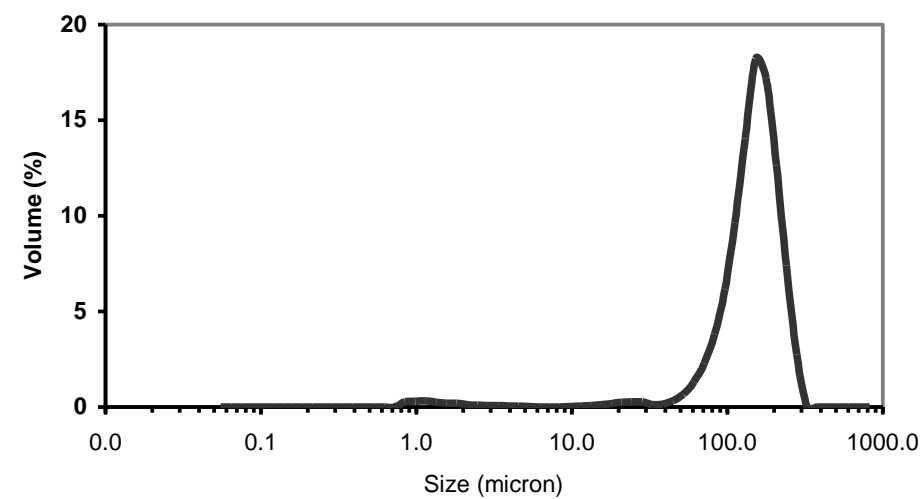

(b)

Fig. 1. Particle size distribution of (a) the HA powder and (b) PMMA granules.

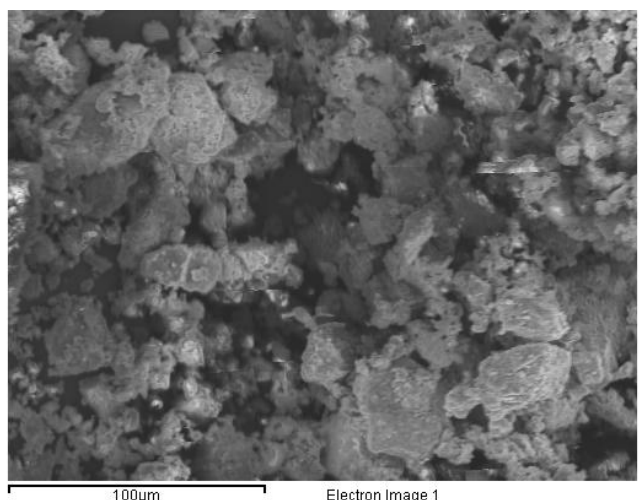

(a)

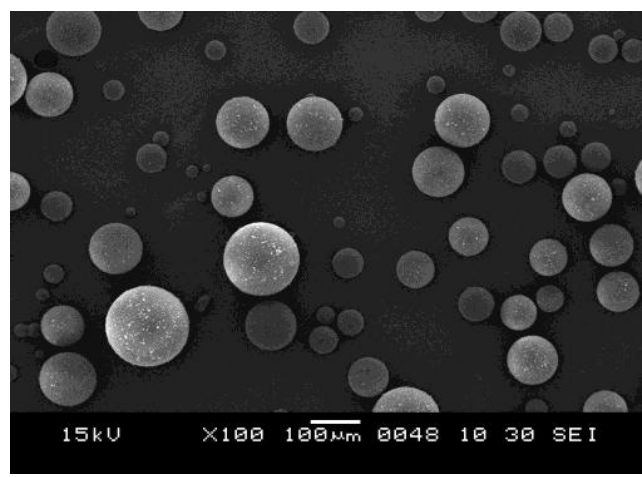

(b)

Fig. 2. Particle morphology through SEM of (a) the HA particle sintered at $1100^{\circ} \mathrm{C}$ for $2 \mathrm{hr}$ and (b) the as-received PMMA granules.

Figure 3 displayed XRD spectra of the HA powder sintered at $1100^{\circ} \mathrm{C}$. The spectra showed the single phase of HA, corresponding to the ICDD standard peak of stoichiometric hydroxyapatite (standard No.09-0432). Furthermore, this result agrees with a previous study in that sintering at high temperature resulted in the sharp and narrow diffraction peaks [16].

Figure 4 illustrated TGA curve of the as-received PMMA granules. A stable weight was attained at about $400^{\circ} \mathrm{C}$, which indicates that the PMMA granules have been completely decomposed at about $400^{\circ} \mathrm{C}$. This results is similar to the previous report by Yao et al [17]. In order to let PMMA decompose completely and avoid the cracks in HA ceramics, the heating rate of the green HA body should be very 
slow at sintering temperature below $400^{\circ} \mathrm{C}$. This is why the heating rate of the samples was set at $1^{\circ} \mathrm{C} / \mathrm{min}$.

Table 2. Average and standard deviation of particle sizes of the prepared HA powders and the asreceived PMMA granules ( $\mathrm{d} 0.1, \mathrm{~d} 0.5$ and $\mathrm{d} 0.9$ were referred to the measured particle size of diameter at 10,50 and $90 \mathrm{Vol} \%$ of the powder particles).

\begin{tabular}{cccc}
\hline \multirow{2}{*}{ Type } & \multicolumn{3}{c}{ Particle size $(\mu \mathrm{m})$} \\
\cline { 2 - 4 } & $\mathrm{d} 0.1$ & $\mathrm{~d} 0.5$ & $\mathrm{~d} 0.9$ \\
\hline HA powder & $1.12 \pm 0.01$ & $4.97 \pm 0.03$ & $26.31 \pm 0.19$ \\
PMMA granule & $82.69 \pm 0.27$ & $150.75 \pm 0.15$ & $222.95 \pm 0.49$ \\
\hline
\end{tabular}

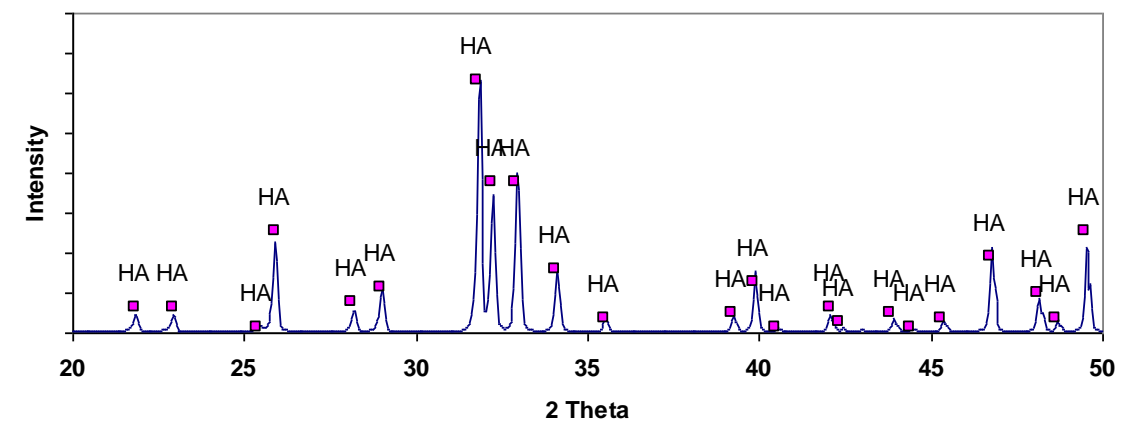

Fig. 3. XRD spectra of the synthesized HA powder sintered at $1100^{\circ} \mathrm{C}$ for $2 \mathrm{~h}$.

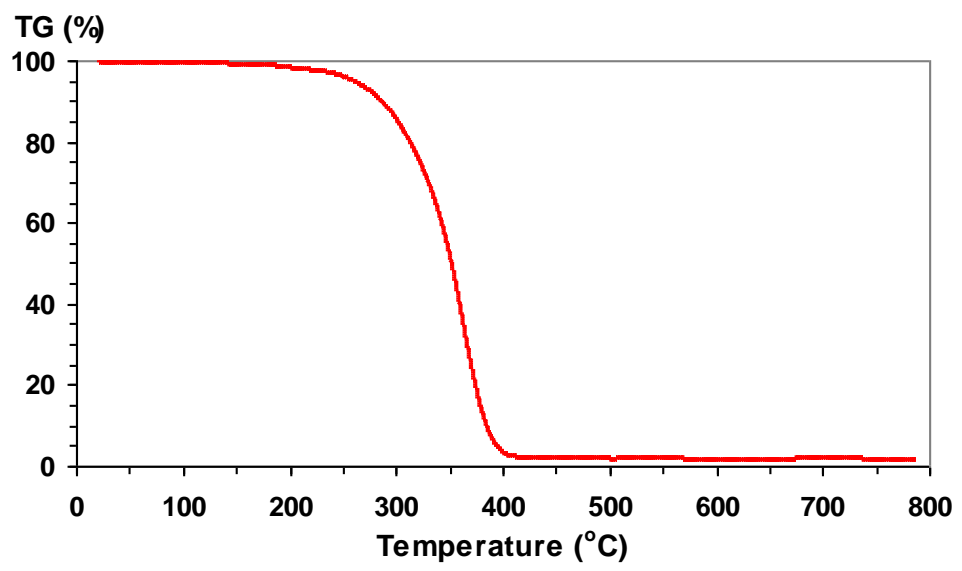

Fig. 4. TGA curve of the as-received PMMA granules.

\subsection{Effect of PMMA and $\mathrm{H}_{2} \mathrm{O}_{2}$ on porosity}

Table 1 showed the feasible production range of the porous HA samples in this study. The samples prepared using only PMMA at the content of over $40 \mathrm{wt} \%$ were handless, while the samples mixed with $\mathrm{H}_{2} \mathrm{O}_{2}$ solution at the concentration of over $20 \mathrm{wt} \%$ were very brittle. To prepare the samples using both PMMA and $\mathrm{H}_{2} \mathrm{O}_{2}$, a balance between the PMMA content and the $\mathrm{H}_{2} \mathrm{O}_{2}$ concentration must be considered as shown in Table 1.

Figure 5 presented effect of PMMA content and $\mathrm{H}_{2} \mathrm{O}_{2}$ concentration on porosity of the HA samples performed by various techniques: (a) sacrificial template; (b) direct foaming; and (c) combination between sacrificial and direct foaming. Table 3 summarized P-value from analysis of variance (ANOVA) for porosity of the porous HA samples prepared by various forming methods (at $\alpha=0.05$ ). 
Table 4 listed the regression models and R-square values from regression analysis for porosity of the porous HA samples prepared by various methods.

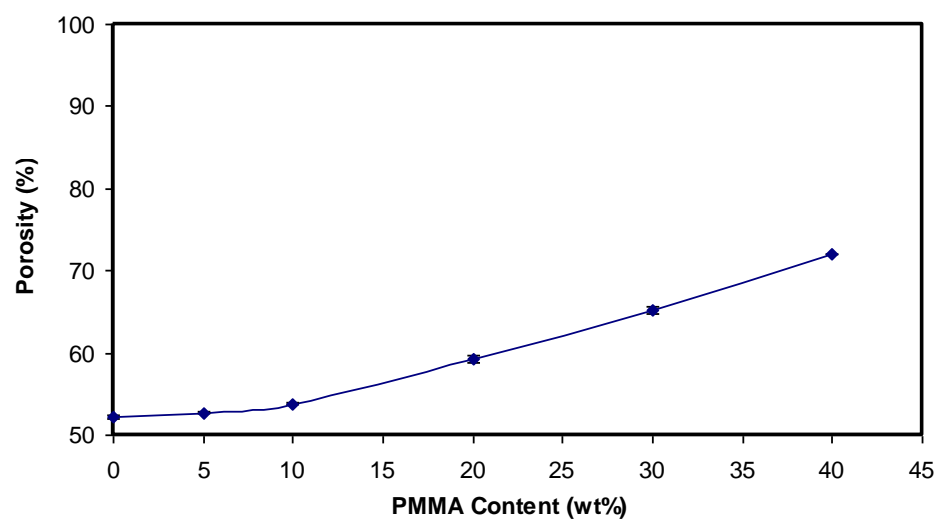

(a) Sacrificial template using PMMA

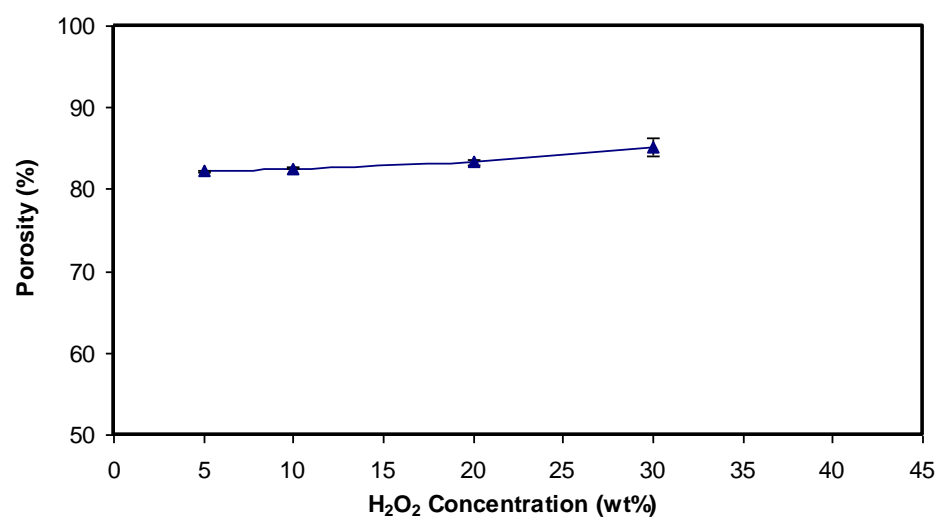

(b) Direct foaming using $\mathrm{H}_{2} \mathrm{O}_{2}$

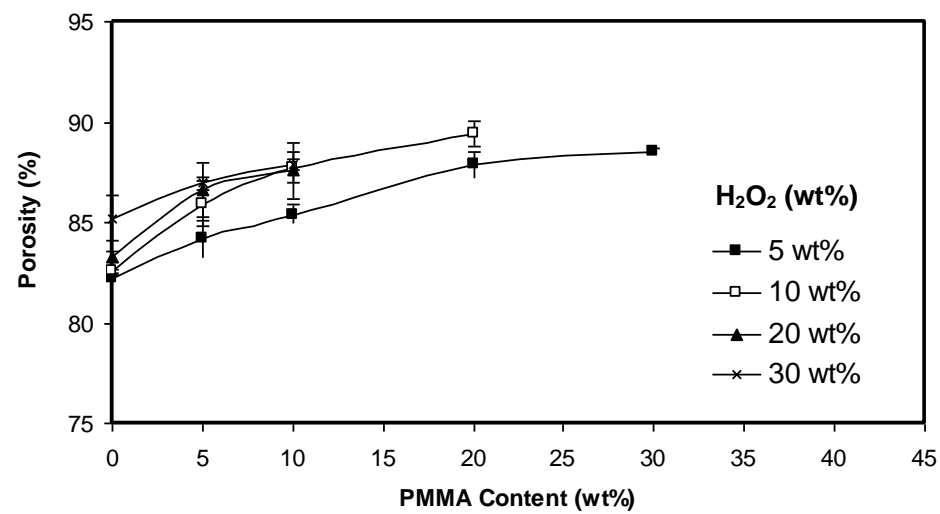

(c) Combination technique using PMMA and $\mathrm{H}_{2} \mathrm{O}_{2}$

Fig. 5. Effect of PMMA content and $\mathrm{H}_{2} \mathrm{O}_{2}$ concentration on porosity of the HA sample performed by various techniques: (a) sacrificial template using PMMA, (b) direct foaming using $\mathrm{H}_{2} \mathrm{O}_{2}$, and (c) combination technique using PMMA and $\mathrm{H}_{2} \mathrm{O}_{2}$.

Figure 5(a) showed the final porosity of the specimens using PMMA granules as pore template. The porosity of the HA sample (H00-P00) was approximately $52 \%$. Obviously, the porosity increased with an increasing content of PMMA used. This result agreed with a previous study by Yao et al [17]. By this technique, the porosity reached approximately $75 \%$ at the PMMA content of $40 \mathrm{wt} \%$. The relation 
between the porosity $(\mathrm{P})$ and the content of PMMA $\left(\mathrm{C}_{\mathrm{P}}\right)$ was explained by the regression model (1) in Table 4

Figure 5(b) exhibited the porosity of the samples using $\mathrm{H}_{2} \mathrm{O}_{2}$ solution as pore former. The porosity of the samples increased slightly from $\sim 82 \%$ up to $\sim 85 \%$, when the concentration of $\mathrm{H}_{2} \mathrm{O}_{2}$ increased from $5 \mathrm{wt} \%$ to $30 \mathrm{wt} \%$. To confirm the effect of $\mathrm{H}_{2} \mathrm{O}_{2}$ concentration on porosity, ANOVA test was performed. This statistical analysis confirmed that the concentration of hydrogen peroxide had a significant effect on porosity, with the P-value of 0.022 , at $95 \%$ confident interval, as shown in Table 3 . Furthermore, the porosity of the samples using $\mathrm{H}_{2} \mathrm{O}_{2}$ less than $5 \mathrm{wt} \%$ could be predicted by the regression model (2) in Table 4. However, compared to the sample $\mathrm{H} 00-\mathrm{P} 00$, adding $\mathrm{H}_{2} \mathrm{O}_{2}(5 \mathrm{wt} \%)$ resulted in a dramatic increase in porosity of about $30 \%$. This was because the addition of $\mathrm{H}_{2} \mathrm{O}_{2}$ into ceramic slurry produced gas voids when it was stored at $60^{\circ} \mathrm{C}$, although a small amount of $\mathrm{H}_{2} \mathrm{O}_{2}$ was applied [10]. At elevated temperature, $\mathrm{H}_{2} \mathrm{O}_{2}$ could produce $\mathrm{H}_{2}$ and $\mathrm{O}_{2}$ gases, leading to the voids in ceramic bodies. The gas voids were driven out by heating during the liquid phase. After drying process, the gas voids remaining in the paste became the pores in porous dry bodies.

Figure 5(c) illustrated the porosity of the porous samples prepared through combination technique using PMMA granule and $\mathrm{H}_{2} \mathrm{O}_{2}$ solution. It seemed a minor change in porosity was found, when both PMMA content and $\mathrm{H}_{2} \mathrm{O}_{2}$ concentration increased. From P-values in Table 3, the content of PMMA had a significant effect on porosity when the $\mathrm{H}_{2} \mathrm{O}_{2}$ concentration was at $5 \mathrm{wt} \%$ and $10 \mathrm{wt} \%$, with the P-value of 0.001 and 0.003 , respectively (at $95 \%$ confident interval). However, at $20 \mathrm{wt} \%$ and $30 \mathrm{wt} \% \mathrm{H}_{2} \mathrm{O}_{2}$, the PMMA content showed an insignificant effect on porosity with the P-value of 0.066 and 0.061 , respectively (at $95 \%$ confident interval). As expected, the samples using $\mathrm{H}_{2} \mathrm{O}_{2}$ with the concentration of over $20 \mathrm{wt} \%$ were hard to be prepared. So, mixing PMMA into these samples had barely affected on porosity. The porosity of the samples using both PMMA and $\mathrm{H}_{2} \mathrm{O}_{2}$ could be estimated by the regression model (3) in Table 4.

From above results, it seemed that the porosity derived from PMMA granules was dominated by $\mathrm{H}_{2} \mathrm{O}_{2}$ solution. This was because PMMA granule formed pores by decomposition at above $400^{\circ} \mathrm{C}$ in solid state while $\mathrm{H}_{2} \mathrm{O}_{2}$ produced pores by expansion of gas voids in liquid phase, which provide the higher porosity than PMMA.

Table 3. Analysis of variance for porosity of the porous HA samples prepared by various methods (at $\alpha$ $=0.05$ ).

\begin{tabular}{llc}
\hline \multicolumn{1}{c}{ Method } & Factor & P-value \\
\hline 1. Sacrificial template using PMMA & Content of PMMA & $<0.001$ \\
\hline 2. Direct foaming using $\mathrm{H}_{2} \mathrm{O}_{2}$ & Concentration of $\mathrm{H}_{2} \mathrm{O}_{2}$ & 0.022 \\
& & \\
\hline 3. Combination technique using PMMA and $\mathrm{H}_{2} \mathrm{O}_{2}$ & & 0.001 \\
3.1. at $5 \mathrm{wt} \% \mathrm{H}_{2} \mathrm{O}_{2}$ & Content of PMMA & 0.003 \\
3.2. at $10 \mathrm{wt} \% \mathrm{H}_{2} \mathrm{O}_{2}$ & Content of PMMA & 0.066 \\
3.3. at $20 \mathrm{wt} \% \mathrm{H}_{2} \mathrm{O}_{2}$ & Content of PMMA & 0.061 \\
3.4. at $30 \mathrm{wt} \% \mathrm{H}_{2} \mathrm{O}_{2}$ & Content of PMMA & \\
\hline
\end{tabular}


Table 4. Regression analysis of the porous $\mathrm{HA}$ samples prepared by various methods ( $\mathrm{P}$ was referred to the expected porosity (\%), $\mathrm{C}_{\mathrm{P}}$ was referred to the content of PMMA (wt\%), and $\mathrm{C}_{\mathrm{H}}$ was referred to the concentration of $\mathrm{H}_{2} \mathrm{O}_{2}$ (wt\%), respectively).

\begin{tabular}{llclc}
\hline \multicolumn{1}{c}{ Method } & Regression Model & R-square \\
\hline $\begin{array}{l}\text { 1. Sacrificial template } \\
\text { using PMMA }\end{array}$ & (1) $\quad \mathrm{P}=0.008 \mathrm{C}_{\mathrm{P}}^{2}+0.204 \mathrm{C}_{\mathrm{P}}+51.716$ & $; 0 \leq \mathrm{C}_{\mathrm{P}} \leq 40$ & 0.9960 \\
\hline $\begin{array}{l}\text { 2. Direct foaming } \\
\text { using } \mathrm{H}_{2} \mathrm{O}_{2}\end{array}$ & (2) $\mathrm{P}=0.004 \mathrm{C}_{\mathrm{H}}{ }^{2}-0.038 \mathrm{C}_{\mathrm{H}}+82.387$ & $; 0<\mathrm{C}_{\mathrm{H}} \leq 30$ & 0.8855 \\
\hline $\begin{array}{l}\text { 3. Combination technique } \\
\text { using PMMA and } \mathrm{H}_{2} \mathrm{O}_{2}\end{array}$ & (3) $\mathrm{P}=-0.012 \mathrm{C}_{\mathrm{P}}^{2}+0.538 \mathrm{C}_{\mathrm{P}}+0.298 \mathrm{C}_{\mathrm{H}}+80.2$ & $; 0 \leq \mathrm{C}_{\mathrm{P}} \leq 20$ & 0.9350 \\
\hline
\end{tabular}

\subsection{Effect of PMMA and $\mathrm{H}_{2} \mathrm{O}_{2}$ on microstructure}

Figure 6 illustrated SEM micrographs of the HA samples prepared with different conditions, after sintering at $1100^{\circ} \mathrm{C}$ for 2 hours. The sintered $\mathrm{HA}$ or the sample of $\mathrm{H} 00-\mathrm{P} 00$ had a few small pores with less than $50 \mu \mathrm{m}$ in diameter, as shown in Fig. 6(a). These pores were derived from driving out of water during drying process.

The porous samples prepared by $10 \mathrm{wt} \%$ and 30wt\% PMMA content were presented in Fig. 6(b) and 6(c), respectively. From the samples, they were composed of two groups of pore size range. The large pore group had the diameter range of 100-300 $\mu \mathrm{m}$, arising from PMMA granules, which conformed to the particle size measured and corresponded to Yao et al [17]. However, it seemed that the small pore group had a similar pore size as seen in the H00-P00 sample. Moreover, the more content of PMMA the higher amount of pores.

The porous samples prepared using $10 \mathrm{wt} \%$ and $20 \mathrm{wt} \% \mathrm{H}_{2} \mathrm{O}_{2}$ concentration were shown in Fig. 6(d) and Fig. 6(e), respectively. By direct foaming technique, the samples had a number of pores with the diameter larger than $100 \mu \mathrm{m}$. Comparison between the sample H10-P00 and H20-P00 indicated that the amount of pores and pore size were increased when using a higher concentration of $\mathrm{H}_{2} \mathrm{O}_{2}$. However, it seemed there were a few pores derived from water. This result is agree with a previous study by Almirall et al [10].

The HA sample prepared through combination technique using 10wt\% PMMA content and 10wt $\%$ $\mathrm{H}_{2} \mathrm{O}_{2}$ concentration was displayed in Fig. 6(f). It seemed that the sample consisted of the large pores in the ceramic body and the small pores in the ceramic wall. The large pore size was up to $1000 \mu \mathrm{m}$ in diameter, while small pore size ranged between 100 and $300 \mu \mathrm{m}$ in diameter. The large pores were possibly resulted from $\mathrm{H}_{2} \mathrm{O}_{2}$, while small pores might be from PMMA granules. Moreover, the interconnected pores were observed. The interconnected pores, pathways between pores, conduct cells and vessels between pores and thus favor bone ingrowth inside ceramics [18].

Based on previous studies, the minimum requirement for pore size is considered to be $\sim 100 \mu \mathrm{m}$ due to cell size, migration requirements and transport. However, pore sizes over $300 \mu \mathrm{m}$ was favorable to enhanced new bone formation and cell regeneration [18, 19]. Therefore, the sample prepared by combination technique using both PMMA and $\mathrm{H}_{2} \mathrm{O}_{2}$ can provide the pores attaining these requirements. 


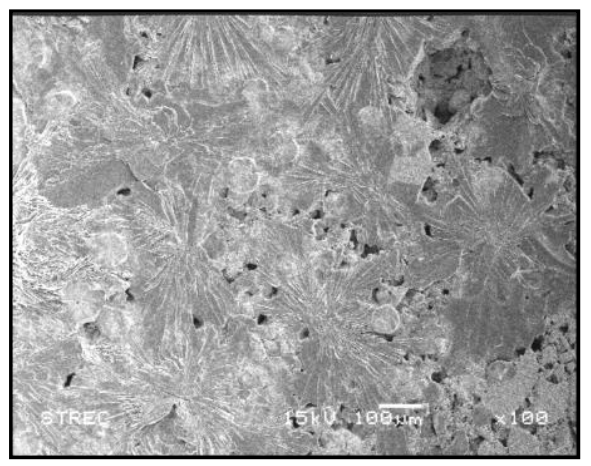

(a) $\mathrm{H} 00-\mathrm{P} 00$

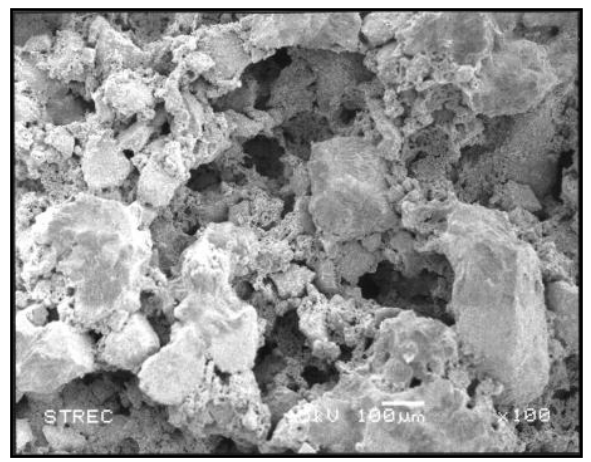

(c) H00-P30

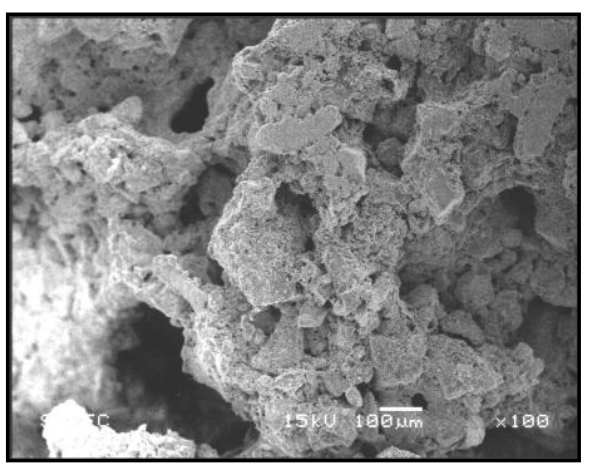

(e) H20-P00

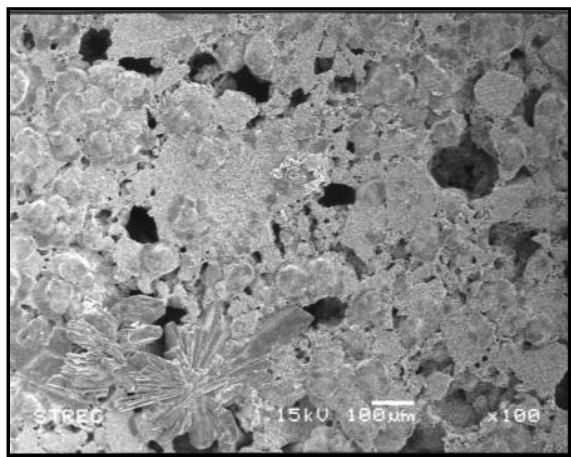

(b) H00-P10

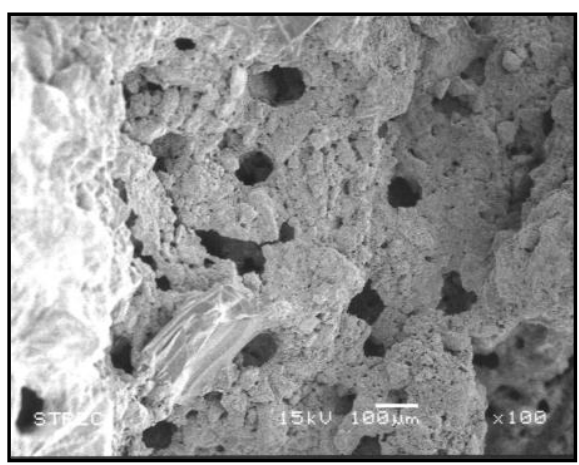

(d) H10-P00

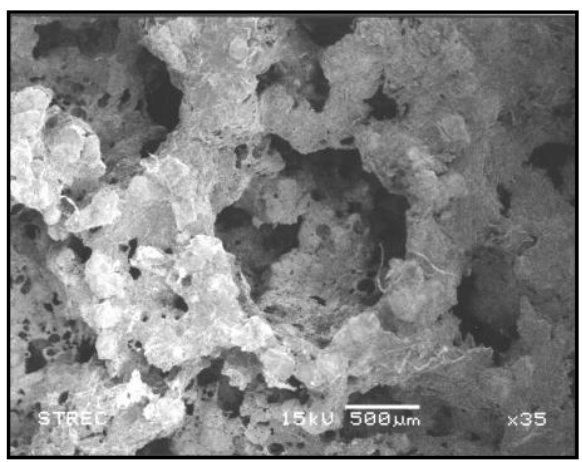

(f) H10-P10

Fig. 6. SEM micrographs of the sintered HA samples prepared with different conditions: (a) H00-P00, (b) H00-P10, (c) H00-P30, (d) H10-P00, (e) H20-P0O and (f) H10-P10.

\subsection{Effect of PMMA and $\mathrm{H}_{2} \mathrm{O}_{2}$ on mechanical strength}

Figure 7 showed the effect of PMMA content and $\mathrm{H}_{2} \mathrm{O}_{2}$ concentration on compressive strength of the HA samples performed by sacrificial template, direct foaming and combination between sacrificial template and direct foaming. In Fig. 7(a), the compressive strength of the samples prepared using PMMA granules dropped from approximately $25 \mathrm{MPa}$ to $0.6 \mathrm{MPa}$ when the template content used increased from $5 \mathrm{wt} \%$ to $40 \mathrm{wt} \%$, while the HA cement (H00-P00) had the compressive strength of around $35 \mathrm{MPa}$. In Fig. 7(b), the compressive strength of the samples prepared using $\mathrm{H}_{2} \mathrm{O}_{2}$ solution decreased from approximately $0.3 \mathrm{MPa}$ to $0.15 \mathrm{MPa}$ when concentration of the foaming agent was increased from $5 \mathrm{wt} \%$ to $30 \mathrm{wt} \%$. Compared to the sample $\mathrm{H} 00-\mathrm{P} 00$, an addition of $\mathrm{H}_{2} \mathrm{O}_{2}$ could affect on falling in compressive strength of the HA samples due to a dramatic increase in porosity [10]. Also, it seemed that $\mathrm{H}_{2} \mathrm{O}_{2}$ has a more influence on impairing the strength than PMMA, because $\mathrm{H}_{2} \mathrm{O}_{2}$ could cause higher porosity than PMMA. In Fig. 7(c), the samples prepared through combination technique 
showed a decrease in compressive strength when using higher PMMA content and higher concentration of $\mathrm{H}_{2} \mathrm{O}_{2}$. In other words, the compressive strength decreases with an increase of final porosity.

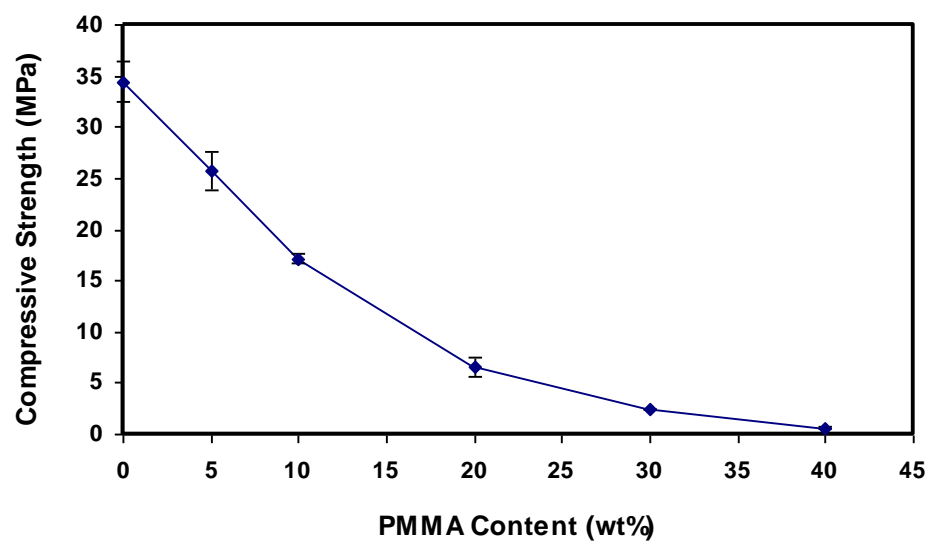

(a) Sacrificial template using PMMA

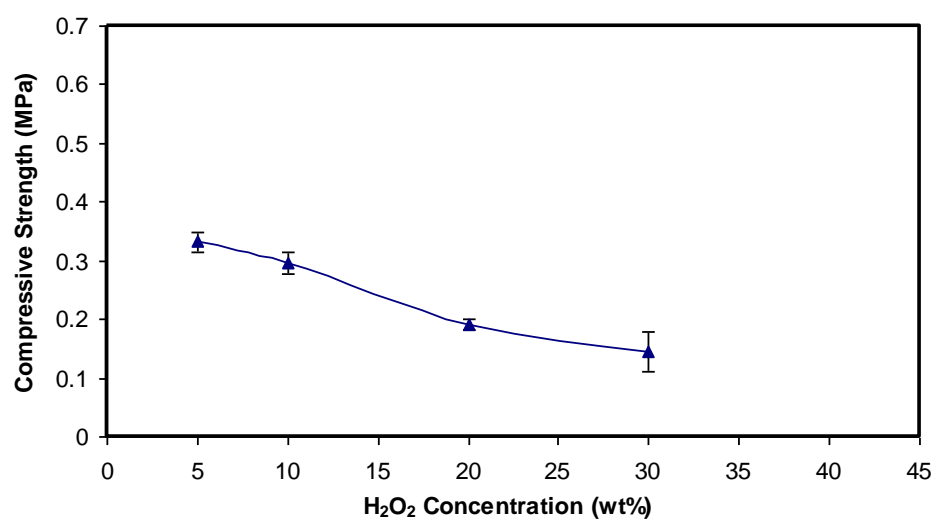

(b) Direct foaming using $\mathrm{H}_{2} \mathrm{O}_{2}$

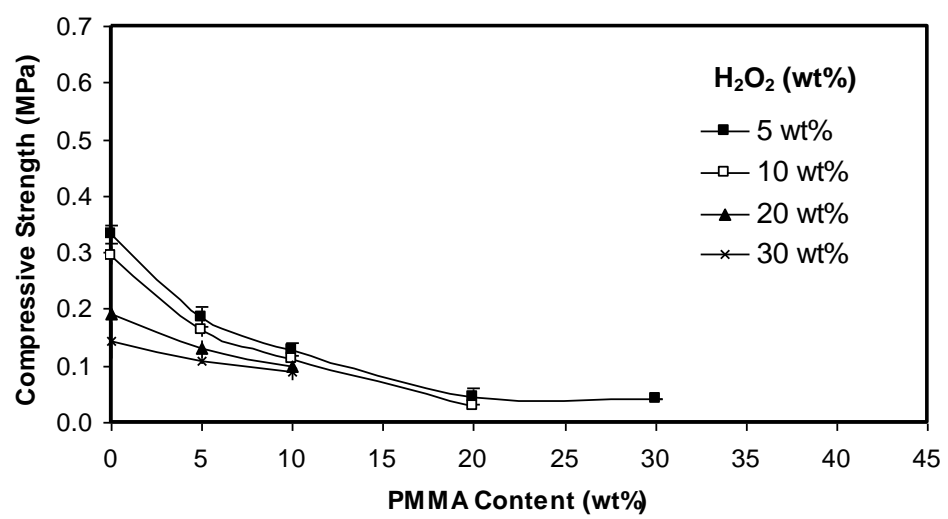

(c) Combination technique using PMMA and $\mathrm{H}_{2} \mathrm{O}_{2}$

Fig. 7. Effect of PMMA content and $\mathrm{H}_{2} \mathrm{O}_{2}$ concentration on compressive strength of the HA samples performed by various techniques: (a) sacrificial template using PMMA, (b) direct foaming using $\mathrm{H}_{2} \mathrm{O}_{2}$, and (c) combination technique using PMMA and $\mathrm{H}_{2} \mathrm{O}_{2}$.

Figure 8 exhibited the effect of PMMA content and $\mathrm{H}_{2} \mathrm{O}_{2}$ concentration on flexural strength of the HA samples performed by sacrificial template, direct foaming and combination between both techniques. The flexural strength of the specimens prepared using PMMA decreased from around 5.5 $\mathrm{MPa}$ to $0.7 \mathrm{MPa}$ when the content of the pore template was raised from $5 \mathrm{wt} \%$ to $40 \mathrm{wt} \%$, as shown in 
Fig. 8(a). The flexural strength of the specimens prepared using $\mathrm{H}_{2} \mathrm{O}_{2}$ was diminished from approximately $0.5 \mathrm{MPa}$ to $0.2 \mathrm{MPa}$ when concentration of the foaming agent increased from $5 \mathrm{wt} \%$ to $30 \mathrm{wt} \%$, as illustrated in Fig. 8(b). As expect, this result is consistent with the compressive strength in that $\mathrm{H}_{2} \mathrm{O}_{2}$ had a more effect than PMMA on the strength. Finally, the specimens prepared through combination technique had a decrease in flexural strength when higher content of PMMA and higher concentration of $\mathrm{H}_{2} \mathrm{O}_{2}$ were added.

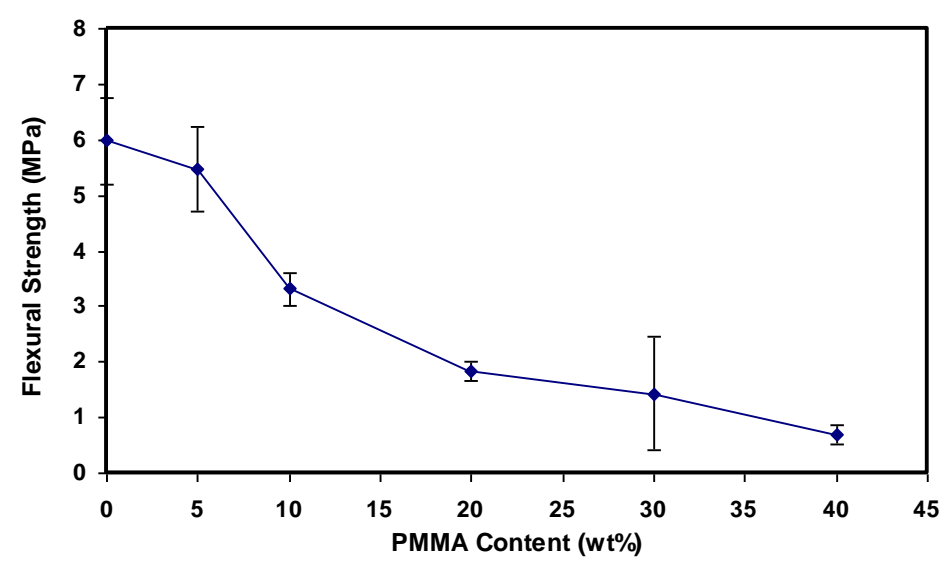

(a) Sacrificial template using PMMA

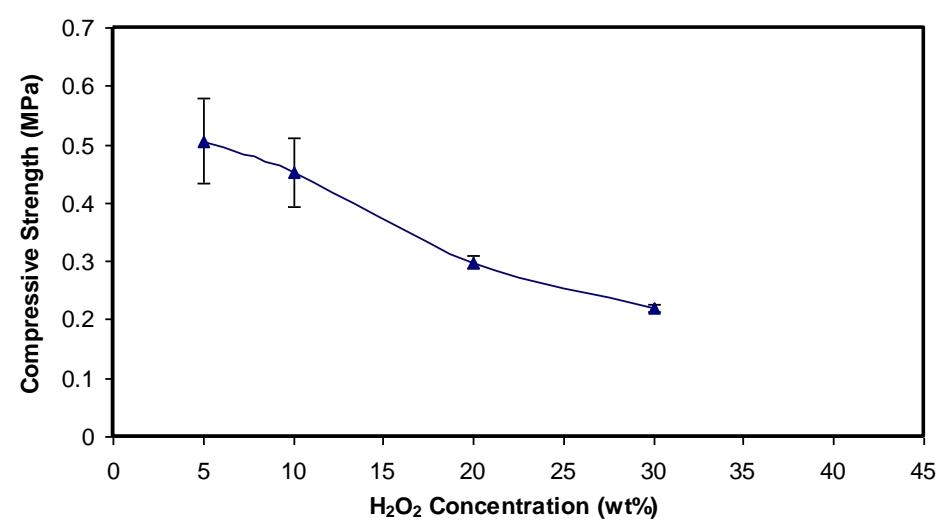

(b) Direct foaming using $\mathrm{H}_{2} \mathrm{O}_{2}$

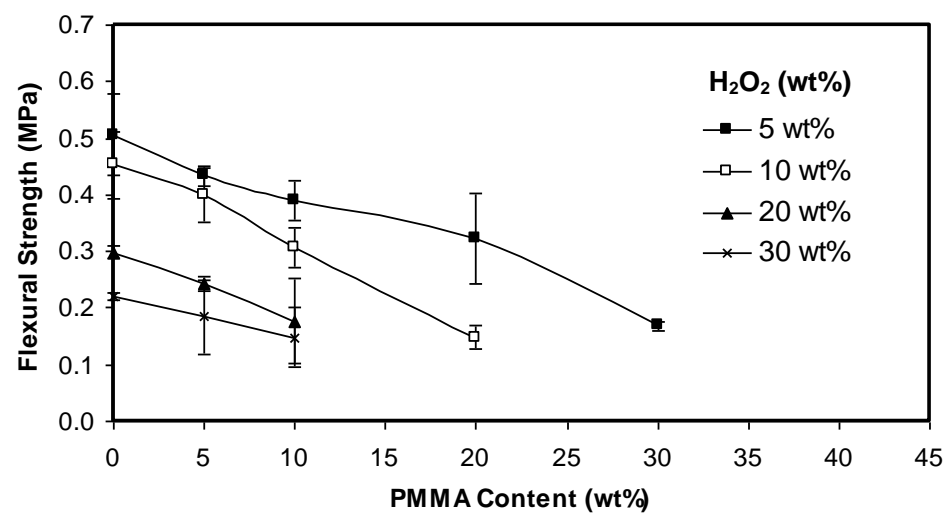

(c) Combination technique using PMMA and $\mathrm{H}_{2} \mathrm{O}_{2}$

Fig. 8. Effect of PMMA content and $\mathrm{H}_{2} \mathrm{O}_{2}$ concentration on flexural strength of the HA samples performed by various techniques: (a) sacrificial template using PMMA, (b) direct foaming using $\mathrm{H}_{2} \mathrm{O}_{2}$, and (c) combination technique using PMMA and $\mathrm{H}_{2} \mathrm{O}_{2}$. 
Figure 9 and Figure 10 presented the effect of porosity on compressive strength and flexural strength, respectively, of the HA samples divided by forming technique, including sacrificial template using PMMA, direct foaming using $\mathrm{H}_{2} \mathrm{O}_{2}$, combination technique using PMMA and $\mathrm{H}_{2} \mathrm{O}_{2}$, and overall techniques.

The samples prepared through sacrificial template using PMMA provided the widest range of mechanical strengths ( 35 to $\sim 1 \mathrm{MPa}$ in compressive strength and 6 to $\sim 1 \mathrm{MPa}$ in flexural strength), as shown in Fig. 9(a) and Fig. 10(a).

The samples prepared by direct foaming using $\mathrm{H}_{2} \mathrm{O}_{2}$ showed a decrease in both strengths (from 0.3 to $\sim 0.1 \mathrm{MPa}$ in compressive strength and from $\sim 0.5$ to $0.2 \mathrm{MPa}$ in flexural strength) when porosity increased, as illustrated in Fig. 9(b) and Fig. 10(b).

The samples using both PMMA and $\mathrm{H}_{2} \mathrm{O}_{2}$ also had a decrease in mechanical strengths $(\sim 0.2-0.05$ $\mathrm{MPa}$ in compressive strength and 0.4-0.1 MPa in flexural strength) when porosity rose, as exhibited in Fig. 9(c) and Fig. 10(c).

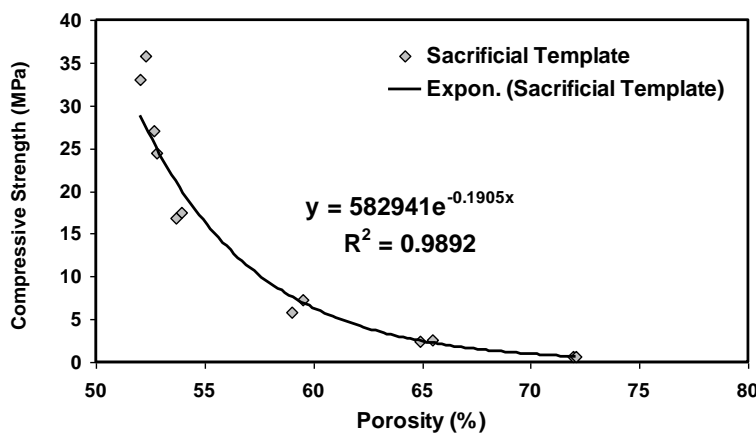

(a) Sacrificial template using PMMA

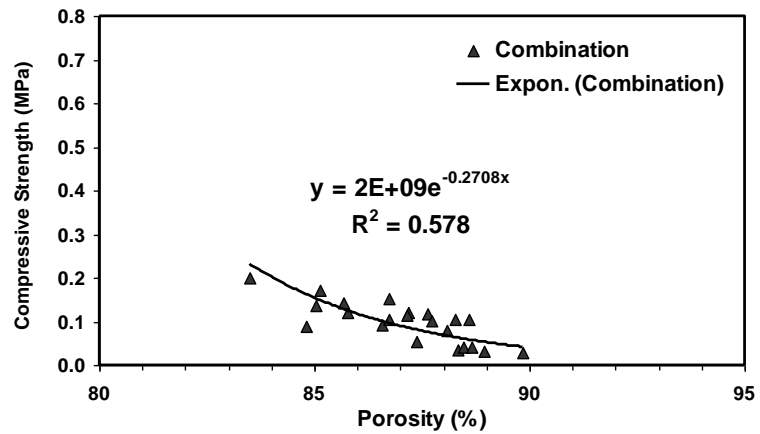

(c) Combination technique using PMMA and $\mathrm{H}_{2} \mathrm{O}_{2}$

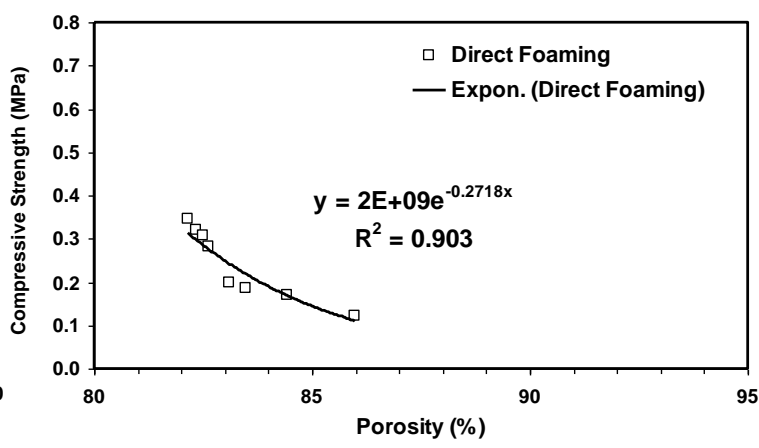

(b) Direct foaming using $\mathrm{H}_{2} \mathrm{O}_{2}$

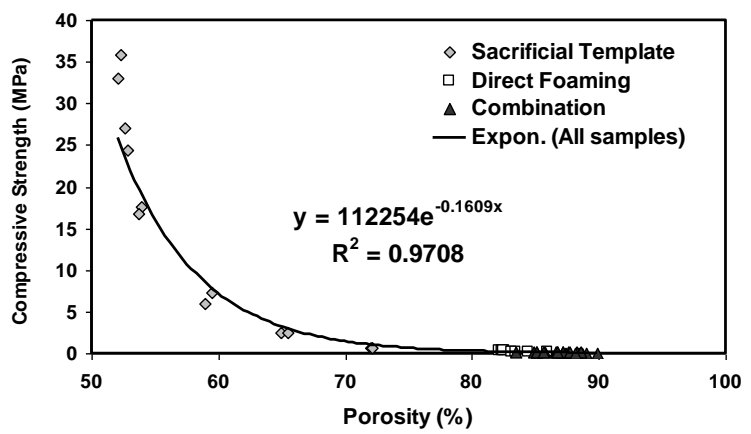

(d) Overall

Fig. 9. Effect of Porosity on compressive strength of the porous HA samples divided by forming techniques: (a) sacrificial template using PMMA, (b) direct foaming using $\mathrm{H}_{2} \mathrm{O}_{2}$, (c) combination technique using PMMA and $\mathrm{H}_{2} \mathrm{O}_{2}$ and (d) overall technique.

It seemed that both compressive strength and flexural strength decreased with an increasing porosity for all forming techniques, as summarized in Fig. 9(d) and Fig. 10(d). These results agreed with previous research that the mechanical strength of the sample was conversely relative to the amount of pore former used and final porosity $[9,10,17]$. Furthermore, the samples with the porosity higher than $80 \%$ showed a fluctuation in strength, particularly flexural strength. On the other hand, the samples using $\mathrm{H}_{2} \mathrm{O}_{2}$ (i.e. direct foaming and combination technique) provided high variation in strength more 
than those using PMMA. This was because the porosity obtained from $\mathrm{H}_{2} \mathrm{O}_{2}$ could not be effectively controlled.

Nevertheless, the mechanical strengths of the samples in this study were lower than the minimum strength of cancellous bone. The minimum compressive strength and flexural strength of human cancellous bone were approximately $2 \mathrm{MPa}$ and $10 \mathrm{MPa}$, respectively [20]. The pore size favorable to bone formation and cell regeneration was over $300 \mu \mathrm{m}$ [19]. As well as the interconnected pores favors to cell ingrowth inside the pore [18]. But, there are no report on suitable porosity for these applications. As a result, such samples were not applicable for a scaffold in bone restoration due to the lack of strength. However, these materials could be applied for fabrication of an eye ball in orbital implant being porous bioceramics.

Furthermore, the low mechanical strengths of porous hydroxyapatite prepared by this combination technique using PMMA and $\mathrm{H}_{2} \mathrm{O}_{2}$ could be developed by adding some additives; such as binder, deflocculant or surfactant. Additionally, using hydrogen peroxide less than $5 \mathrm{wt} \%$ concentration might be another way to improve the strength of the porous samples.

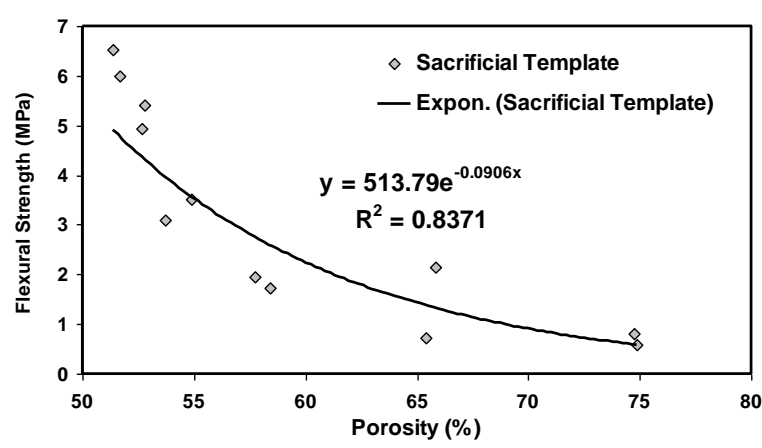

(a) Sacrificial template using PMMA

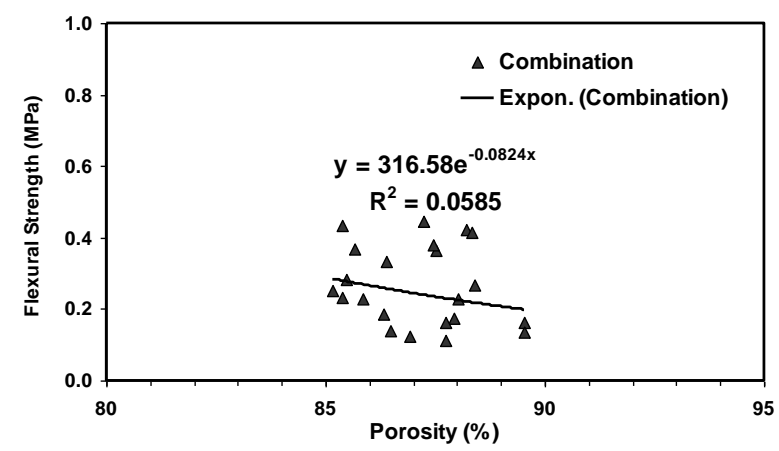

(c) Combination technique using PMMA and $\mathrm{H}_{2} \mathrm{O}_{2}$

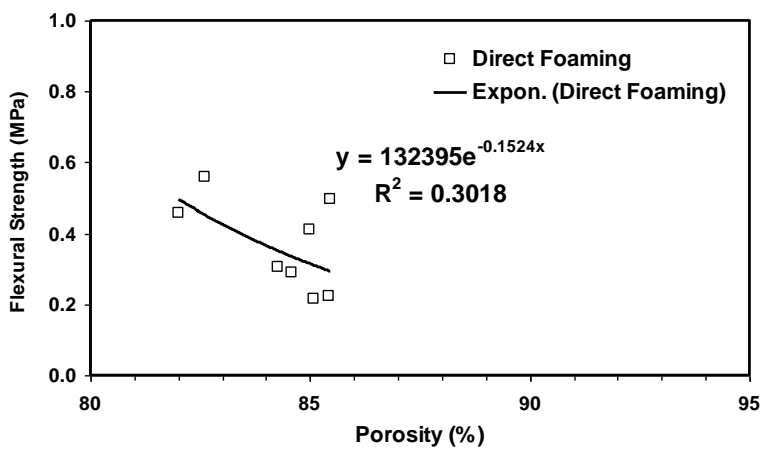

(b) Direct foaming using $\mathrm{H}_{2} \mathrm{O}_{2}$

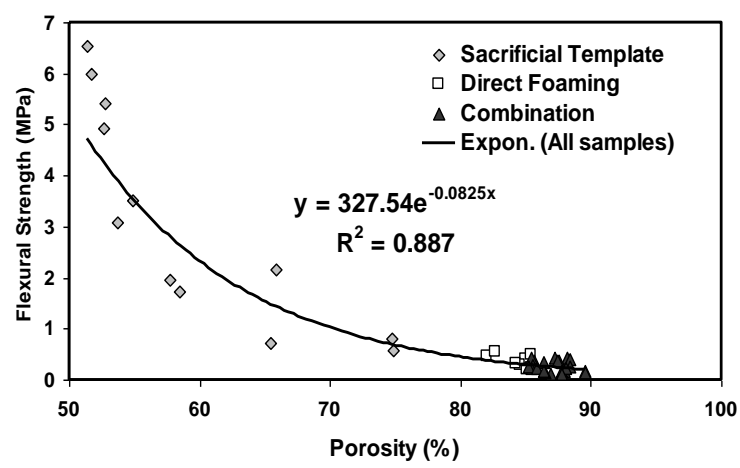

(d) Overall

Fig. 10. Effect of Porosity on flexural strength of the porous HA samples divided by forming techniques: (a) sacrificial template using PMMA, (b) direct foaming using $\mathrm{H}_{2} \mathrm{O}_{2}$, (c) combination technique using PMMA and $\mathrm{H}_{2} \mathrm{O}_{2}$ and (d) overall technique.

\section{Conclusion}

This study investigated the characteristics of the porous HA prepared by three different methods and the effect of pore former on their mechanical properties, summarized as follows:

(1) An increasing porosity of the hydroxyapatite samples resulted in a decrease of both compressive strength and flexural strength. 
(2) For sacrificial template, the more PMMA content had a significant effect on the higher porosity of the HA samples whereas the lower compressive strength and flexural strength. These samples had the pore size ranged between 100 and $300 \mu \mathrm{m}$.

(3) For direct foaming, the higher concentration of $\mathrm{H}_{2} \mathrm{O}_{2}$ resulted in an increase in porosity and pore size, while a decrease in the both mechanical strength. The pore size of these samples ranged from 100 to $1000 \mu \mathrm{m}$.

(4) There were hard to prepare the porous HA using PMMA content over 40wt\% for sacrificial template and $\mathrm{H}_{2} \mathrm{O}_{2}$ concentration over $20 \mathrm{wt} \%$ for direct foaming when $\mathrm{L} / \mathrm{P}$ ratio was controlled at 1.3 $\mathrm{ml} / \mathrm{g}$.

(5) For combination between sacrificial template and direct foaming, an increasing use of PMMA and $\mathrm{H}_{2} \mathrm{O}_{2}$ caused a rise in porosity and a drop in both compressive and flexural strengths.

(6) The HA samples prepared through sacrificial template provided the porosity ranged between $52 \%$ and $75 \%$, while the samples produced by direct foaming and combination technique provided the porosities ranged from $82 \%$ to $85 \%$ and from $84 \%$ to $90 \%$, respectively.

\section{Acknowledgement}

The authors would like to thank the Graduate School and Department of Industrial Engineering, Faculty of Engineering, Chulalongkorn University for financial support and also Department of Material Science and Metallurgy, University of Cambridge for laboratory cooperation.

\section{References}

[1] H. Aoki, Medical Applications of Hydroxyapatite: Takayama Press, 1994.

[2] L. L. Hench, "Bioceramics," Journal of the American Ceramic Society, vol. 81, pp. 1705-1728, 1998.

[3] S. W. K. Kweh, K. A. Khor, and P. Cheang, "The production and characterization of hydroxyapatite (HA) powders," Journal of Materials Processing Technology, vol. 89-90, pp. 373-377, 1999.

[4] A. R. Studart, U. T. Gonzenbach, E. Tervoort, and L. J. Gauckler, "Processing routes to macroporous ceramics: a review," Journal of the American Ceramic Society, vol. 89, pp. 17711789, 2006.

[5] D. C. Tancred, B. A. O. McCormack, and A. J. Carr, "A synthetic bone implant macroscopically identical to cancellous bone," Biomaterials, vol. 19, pp. 2303-2311, 1998.

[6] S.-H. Kwon, Y.-K. Jun, and S.-H. Hong, "Calcium phosphate bioceramics with various porosities and dissolution rates," Journal of the American Ceramic Society, vol. 85, pp. 312931, December 2002.

[7] L. M. Rodriguez-Lorezo, J. Ferreira, and M. Vallet-Regí, "Processing of porous hydroxyapatite by starch consolidation," Bioceramics, vol. 11, pp. 89-92, 1998.

[8] S. H. Li, J. R. de Wijn, and P. Layrolle, "Novel method to manufacture porous hydroxyapatite by dual-phase mixing," Journal of the American Ceramic Society, vol. 86, pp. 65-72, January 2003.

[9] E. J. Lee, Y. H. Koh, B. H. Yoon, H. E. Kim, and H. W. Kim, "Highly porous hydroxyapatite bioceramics with interconnected pore channels using camphene-based freeze casting," Materials Letters, vol. 61, pp. 2270-2273, 2007.

[10] A. Almirall, G. Larrecq, J. A. Delgado, S. Martínez, J. A. Planell, and M. P. Ginebra, "Fabrication of low temperature macroporous hydroxyapatite scaffolds by foaming and hydrolysis of an $\alpha$-TCP paste," Biomaterials, vol. 25, pp. 3671-3680, 2004.

[11] P. Sepulveda, F. S. Ortega, M. D. M. Innocentini, V. C. Pandolfelli, and D. Green, "Properties of highly porous hydroxyapatite obtained by the gelcasting of foams," Journal of the American Ceramic Society, vol. 83, p. 3021, 2000.

[12] S. Padilla, J. Romàn, and M. Vallet-Regí, "Synthesis of porous hydroxyapatites by combination of gelcasting and foams burn out methods," Journal of Materials Science: Materials in Medicine, vol. 13, pp. 1193-1197, 2002. 
[13] C. Bartuli, E. Bemporad, J. M. Tulliani, J. Tirillò, G. Pulci, and M. Sebastiani, "Mechanical properties of cellular ceramics obtained by gel casting: Characterization and modeling," Journal of the European Ceramic Society, vol. 29, pp. 2979-2989, 2009.

[14] I. R. Gibson, S. Ke, S. M. Best, and W. Bonfield, "Effect of powder characteristics on the sinterability of hydroxyapatite powders," Journal of Materials Science: Materials in Medicine, vol. 12, pp. 163-171, 2001.

[15] E. Bouyer, F. Gitzhofer, and M. I. Boulos, "Morphological study of hydroxyapatite nanocrystal suspension," Journal of Materials Science: Materials in Medicine, vol. 11, pp. 523-531, 2000.

[16] N. Patel, I. R. Gibson, S. Ke, S. M. Best, and W. Bonfield, "Calcining influence on the powder properties of hydroxyapatite," Journal of Materials Science: Materials in Medicine, vol. 12, pp. 181-188, 2001.

[17] X. Yao, S. Tan, and D. Jiang, "Improving the properties of porous hydroxyapatite ceramics by fabricating methods," Journal of Materials Science, vol. 40, pp. 4939-4942, 2005.

[18] J. X. Lu, B. Flautre, K. Anselme, P. Hardouin, A. Gallur, M. Descamps, and B. Thierry, "Role of interconnections in porous bioceramics on bone recolonization in vitro and in vivo," Journal of Materials Science: Materials in Medicine, vol. 10, pp. 111-120, 1999.

[19] V. Karageorgiou and D. Kaplan, "Porosity of 3D biomaterial scaffolds and osteogenesis," Biomaterials, vol. 26, pp. 5474-5491, 2005.

[20] A. A. White, S. M. Best, and I. A. Kinloch, "Hydroxyapatite-carbon nanotube composites for biomedical applications: A review," International Journal of Applied Ceramic Technology, vol. 4, pp. 1-13, 2007. 
